\title{
Sphingobium lactosutens sp. nov., isolated from a hexachlorocyclohexane dump site and Sphingobium abikonense sp. nov., isolated from oil-contaminated soil
}

\author{
Hansi Kumari, Sanjay Kumar Gupta, Swati Jindal, Parul Katoch \\ and Rup Lal
}

Correspondence

Rup Lal

duzdel@vsnl.com
Molecular Biology Laboratory, Department of Zoology, University of Delhi, Delhi 110007, India
While investigating microbial diversity of a hexacholorocyclohexane $(\mathrm{HCH})$ dumpsite in Ummari village, Lucknow, India, with $\mathrm{HCH}$ levels between $1.3 \times 10^{4}$ and $3.9 \times 10^{5} \mathrm{ppm}$, a yellow-pigmented bacterial strain, DS20 ${ }^{\mathrm{T}}$, was isolated using the method as described by Singh \& Lal (2009). Even though isolated from such a highly contaminated site, strain DS20 ${ }^{\mathrm{T}}$ was found to not degrade $\mathrm{HCH}$.

The phylogenetic tree based on 16S rRNA gene sequences showed that strain DS20 ${ }^{\mathrm{T}}$ belonged to the Sphingobium cluster, showing closest similarity to 'Pseudomonas abikonensis' IAM 12404 (98.8\%). 'Pseudomonas abikonensis' IAM 12404 was isolated from an oil-contaminated soil and is able to metabolize dibenzothiophene to sulfur-containing organic acid compounds (Anzai et al., 2000; Yamada et al., 1968). Thus, the taxonomic position of ' $P$.

Abbreviations: FAME, fatty acid methyl ester; $\mathrm{HCH}$, hexachlorocyclohexane.

The GenBank/EMBL/DDBJ accession numbers for the 16S rRNA gene sequences of Sphingobium lactosutens $\mathrm{DS}^{\top} \mathrm{O}^{\top}$ and Sphingobium abikonense IAM $12404^{\top}$ are EU675846 and AB021416, respectively.

Tables of fatty acid compositions and signature sequences and figures showing polar lipid patterns and transmission electron micrographs for Sphingobium lactosutens DS20 ${ }^{\top}$ and Sphingobium abikonense NBRC $16140^{\top}$ are available as supplementary material with the online version of this paper. abikonensis' NBRC 16140 was also reassessed. In the past, many incompletely characterized, polar-flagellated, Gramnegative, rod-shaped, aerobic bacteria have been clustered into the genus Pseudomonas (Anzai et al., 2000) and most of them have been subsequently reclassified and transferred to other genera (Vandamme et al., 1997; Viallard et al., 1998; Grimes et al., 1997; Spröer et al., 1998; Nohynek et al., 1996; Kim et al., 2000). 'P. abikonensis' IAM 12404 was, in fact, included in the Sphingomonas cluster on the basis of 16S rRNA gene sequence comparisons by Anzai et al. (2000) and the need for further taxonomic characterization was suggested (Anzai et al., 2000; Lee et al., 2005). The polyphasic approach used in this study suggested that strain DS20 ${ }^{\mathrm{T}}$ and 'P. abikonensis' NBRC 16140 represent two distinct species of the genus Sphingobium.

The 16S rRNA gene sequence analysis of strain DS20 ${ }^{\mathrm{T}}$ was performed as described by Gupta et al. (2008) using a 3100-Avant Genetic Analyzer sequencer (Applied Biosystems) at the Department of Zoology, University of Delhi. A continuous stretch of 1334 bp for the 16S rRNA gene sequence of strain DS20 ${ }^{\mathrm{T}}$ was checked for quality and gaps. Similarity searches were performed using the sequence match program of the Ribosomal Database Project (http://rdp.cme.msu.edu/) and BLAST program of NCBI (http://www.ncbi.nlm.nih.gov/blast/Blast.cgi). For 
the construction of the phylogenetic tree, nearly complete $16 \mathrm{~S}$ rRNA gene sequences of all 15 Sphingobium species with validly published names were retrieved from GenBank. The selected sequences were aligned using CLUSTAL x (Thompson et al., 1997), terminal nucleotides not present in all of the sequences were removed manually from the alignment file and phylogenetic analysis was carried out using PHYLIP version 3.5 (Felsenstein, 1993) and TREECON (Van de Peer \& De Wachter, 1994). The evolutionary distance matrix was calculated according to the model of Jukes \& Cantor (1969) and clustering with neighbour joining (Saitou \& Nei, 1987) was performed. Phylogenetic analysis was also done with the parsimony method (Fitch, 1971) using DNAPARS. Calculation of bootstrap values were based on 1000 resamplings.

The topology of the phylogenetic tree (Fig. 1) revealed that strain $\mathrm{DS}^{\mathrm{T}}{ }^{\mathrm{T}}$ and 'P. abikonensis' IAM 12404 formed a monophyletic clade with species of the genus Sphingobium. Strain DS $20^{\mathrm{T}}$ shared $98.8 \%$ sequence similarity with ' $P$. abikonensis' IAM 12404, 97.4\% with Sphingobium rhizovicinum CC-FH12-1 ${ }^{\mathrm{T}}, 97.2 \%$ with Sphingobium olei IMMIB HF-1 ${ }^{\mathrm{T}}$, $96.7 \%$ with Sphingobium amiense $\mathrm{YT}^{\mathrm{T}}$ and $96.5 \%$ with Sphingobium cloacae S-3 ${ }^{\mathrm{T}}$. P. abikonensis' IAM 12404 shared $96.8 \%$ similarity with both $S$. rhizovicinum CCFH12- $1^{\mathrm{T}}$ and S. olei IMMIB HF-1 ${ }^{\mathrm{T}}, 96.3 \%$ sequence similarity with $S$. amiense $\mathrm{YT}^{\mathrm{T}}$ and $96.1 \%$ with $S$. cloacae
S-3 $3^{\mathrm{T}}$. Strain DS $20^{\mathrm{T}}$ and 'P. abikonensis' IAM 12404 showed sequence similarities of $93-96 \%$ with other members of the genus Sphingobium. Additionally, the $16 \mathrm{~S}$ rRNA gene sequences of strain DS20 ${ }^{\mathrm{T}}$ and 'P. abikonensis' IAM 12404 were found to contain the nucleotide-specific signatures for the genus Sphingobium cluster II (Takeuchi et al., 2001) (Supplementary Table S1, available in IJSEM Online). This indicated that both strains belonged to the genus Sphingobium and further analyses were done to confirm their phylogenetic positions.

To further clarify the taxonomic status of strain $\mathrm{DS}^{\mathrm{T}} \mathrm{O}^{\mathrm{T}}$ and 'P. abikonensis' NBRC 16140, DNA-DNA hybridization studies were carried out between strain $\mathrm{DS}^{2} 0^{\mathrm{T}}$, ' $P$. abikonensis' NBRC 16140, S. olei IMMIB HF- ${ }^{\mathrm{T}}$, $S$. rhizovicinum CC-FH12-1 ${ }^{\mathrm{T}}$, S. amiense $\mathrm{YT}^{\mathrm{T}}$, S. cloacae S$3^{\mathrm{T}}$ and Sphingobium xenophagum DSM $6383^{\mathrm{T}}$ as described by Pal et al. (2005). The amount of bound probe DNA was estimated using a scintillation counter (Beckman Instruments, USA) and hybridization values were expressed as percentages of bound probe. The DNADNA hybridization data showed $42.3 \%$ DNA-DNA relatedness between strain $\mathrm{DS} 20^{\mathrm{T}}$ and ' $P$. abikonensis' NBRC 16140 and less than 50\% DNA-DNA relatedness between either strain $\mathrm{DS}^{\mathrm{T}} \mathrm{T}^{\mathrm{T}}$ or 'P. abikonensis' NBRC 16140 and other related Sphingobium strains, including S. olei IMMIB $\mathrm{HF}^{\mathrm{T}}{ }^{\mathrm{T}}$, S. rhizovicinum CC-FH12-1 ${ }^{\mathrm{T}}$,

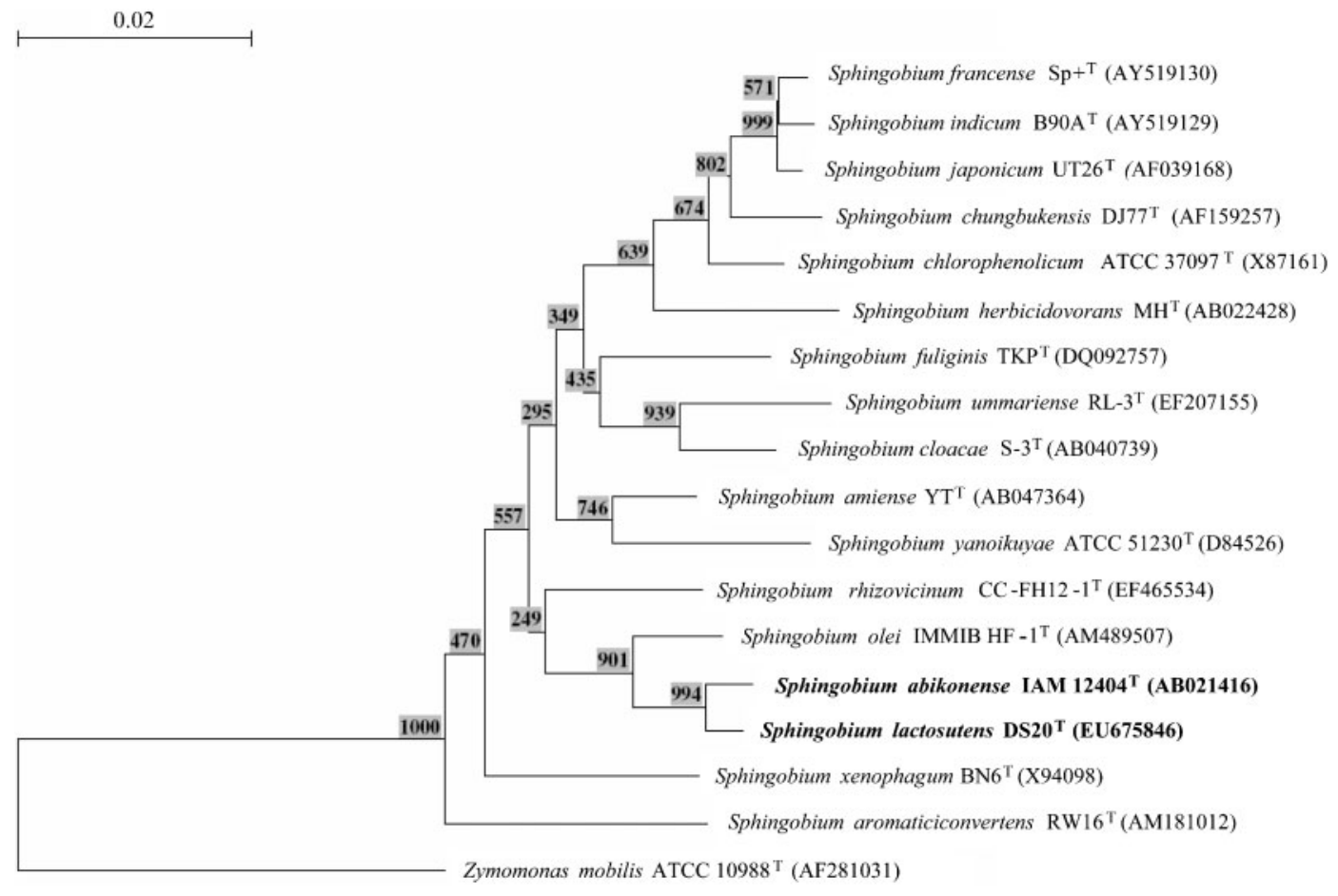

Fig. 1. Phylogenetic tree based on $16 \mathrm{~S}$ rRNA gene sequences showing the phylogenetic relationships of strains $D S 20^{\top}$ and IAM $12404^{\top}$ with related species, constructed using the neighbour-joining method. Zymomonas mobilis ATCC $10988^{\top}$ was used as the outgroup. Bootstrap values based on 1000 resamplings are shown at branch nodes. Bar, 0.02 substitutions per nucleotide position. 
S. amiense $\mathrm{YT}^{\mathrm{T}}$, S. cloacae $\mathrm{S}-3^{\mathrm{T}}$ and S. xenophagum DSM $6383^{\mathrm{T}}$. The pooled standard deviations of all of the hybridization experiments were between 3 and $7 \%$. The hybridization results were below the threshold of $70 \%$ set by Wayne et al. (1987) for the delineation of bacterial species and clearly indicated that strain $\mathrm{DS}^{\mathrm{T}} 0^{\mathrm{T}}$ and ' $P$. abikonensis' NBRC 16140 are representatives of two distinct novel species of the genus Sphingobium.

Fatty acid methyl ester (FAME) analysis was carried out at the Institute of Microbial Technology (IMTECH), Chandigarh, India. Bacterial cultures were harvested by centrifugation and the pellets were subjected to saponification, methylation and extraction, using the methods described by Miller (1982) and Kuykendall et al. (1988). The analysis was done using the Sherlock Microbial Identification System (MIDI, USA). The FAME analysis of both strain $\mathrm{DS}^{2} 0^{\mathrm{T}}$ and 'P. abikonensis' NBRC 16140 showed the presence of 2-hydroxy fatty acids and the absence of 3-hydroxy fatty acids, which are characteristic features of the family Sphingomonadaceae (Busse et al., 1999). Further analysis revealed that strain $\mathrm{DS}^{2} 0^{\mathrm{T}}$ and ' $P$. abikonensis' NBRC 16140 showed FAME profiles that are characteristic of the genus Sphingobium (Takeuchi et al., 2001) with the predominance of $18: 1 \omega 7 c$ (59.5 and $67.6 \%$, respectively), $16: 0$ (5.9 and $5.7 \%$, respectively), 14:0 2-OH (10.4 and 7.2\%, respectively) and summed feature $3(16: 1 \omega 7 c$ and/or $16: 1 \omega 6 c ; 10.8$ and $10.4 \%$, respectively). However, the quantitative differences in the fatty acid profiles indicated that strain $\mathrm{DS}^{\mathrm{T}} \mathrm{T}^{\mathrm{T}}$ and ' $P$. abikonensis' NBRC 16140 represent distinct species of the genus Sphingobium (Supplementary Table S2, in IJSEM Online).

Polar lipid extraction was performed as described by Gupta et al. (2009). Polar lipids were identified by comparing $R_{\mathrm{f}}$ values with commercially prepared standards (Sigma) and lipids extracted from reference type strains. The examination of total polar lipids of strain $\mathrm{DS}^{\mathrm{T}} 0^{\mathrm{T}}$ and ' $P$. abikonensis' NBRC 16140 revealed the presence of polar lipids that are commonly found in Sphingobium species. Comparison with the standards identified phosphatidylmonomethylethanolamine, phosphatidylethanolamine, phosphatidylglycerol, phosphatidyldimethylethanolamine, diphosphatidylglycerol, sphingoglycolipid, phosphatidylcholine and an unidentified polar lipid. Although the major lipids were found in both strain $\mathrm{DS}^{\mathrm{T}} \mathrm{T}^{\mathrm{T}}$ and ' $P$. abikonensis' NBRC 16140, there were differences: phosphatidylcholine was detected in strain DS20 $20^{\mathrm{T}}$ but not in ' $P$. abikonensis' NBRC 16140 (Supplementary Fig. S1, in IJSEM Online).

Cultural features of strain DS20 ${ }^{\mathrm{T}}$ and ' $P$. abikonensis' NBRC 16140 were studied on Luria-Bertani (LB) agar plates after incubation at $28{ }^{\circ} \mathrm{C}$ for $48-72 \mathrm{~h}$. Both strains produced yellow-pigmented circular colonies. Gram-staining was performed using a kit from Himedia (Mumbai, India). Cell morphology was studied using transmission electron micrographs taken at All India Institute of Medical
Sciences (Delhi, India): a loopful of grown culture was suspended in Karnovsky's fixative for $2 \mathrm{~h}$, washed with phosphate buffer and stained with $1 \%$ phosphotungstic acid for observation with a transmission electron microscope (model 269D; Morgagni). Motility was also checked on motility agar (Farmer, 1999). Whereas cells of strain DS $20^{\mathrm{T}}$ were rod-shaped and non-motile without flagella, cells of 'P. abikonensis' NBRC 16140 were rod-shaped with a single polar flagellum (Supplementary Fig. S2, in IJSEM Online).

Growth at different temperatures $\left(4-50^{\circ} \mathrm{C}\right)$ was examined. Growth at different $\mathrm{pH}$ values (4-12) and salt concentrations $(1-10 \%)$ were examined at $28{ }^{\circ} \mathrm{C}$. Acid production from carbohydrates and degradation of xanthine and hypoxanthine were tested as described by Gordon et al. (1974). Catalase test and growth at different temperatures was carried out as described by McCarthy \& Cross (1984). Hydrolysis of aesculin and Tween 20 and the ability of the strains to grow in the presence of $\mathrm{NaCl}$ were tested as described by Arden-Jones et al. (1979). Hydrolysis of gelatin and starch was carried out as described by Cowan \& Steel (1965). Urease activity was detected as described by Christensen (1946). Nitrate reduction was tested according to Smibert \& Krieg (1994). Other physiological methods were used as described by Collins et al. (1989). Antibiotic sensitivity was checked on Mueller-Hinton II medium (Himedia; India) using ready-made discs (Himedia) with varying amount of antibiotics, from 5 to $30 \mu \mathrm{g} /$ disc. The results that differentiate the strains from 13 species of the genus Sphingobium are listed in Table 1.

To conclude, the results of the phylogenetic, chemotaxonomic and morphological analyses clearly place strain $\mathrm{DS}^{2}{ }^{\mathrm{T}}$ and ' $P$. abikonensis' NBRC 16140 in the genus Sphingobium as representing two novel species, for which the names Sphingobium lactosutens sp. nov. and Sphingobium abikonense sp. nov., are proposed.

\section{Description of Sphingobium lactosutens sp. nov.}

Sphingobium lactosutens (lac.to.su'tens. N.L. n. lactosum lactose; L. v. utor to use, make use of, employ; N.L. part. adj. lactosutens using lactose, assimilating lactose).

Cells are Gram-negative, aerobic, non-spore-forming, nonmotile and rod-shaped $(2.6 \mu \mathrm{m} \times 1.3 \mu \mathrm{m})$. Produces yellow-coloured, small, smooth and circular colonies. Grows at $20-37{ }^{\circ} \mathrm{C}$ (optimum, $28{ }^{\circ} \mathrm{C}$ ) and $\mathrm{pH}$ 6-10 (optimum, $\mathrm{pH} 7$ ). Does not grow in $>5 \% \mathrm{NaCl}$. Produces acid from D-glucose, D-galactose, L-arabinose, D-xylose, lactose, cellobiose, maltose and trehalose but not from D-mannose, D-fructose, sucrose, D-ribose, D-mannitol, raffinose, rhamnose, melibiose, meso-inositol, adonitol or sorbitol. Positive for aesculin hydrolysis, citrate utilization and nitrate reduction. Negative for urease, catalase, gelatinase, xanthine and hypoxanthine hydrolysis, DNase and starch hydrolysis. Sensitive to ( $\mu \mathrm{g}$ per disc): ciprofloxacin (5), rifampicin (5), kanamycin (30), vancomycin (30), gentamicin (10), tetracycline (30), chloramphenicol (30), 
Table 1. Differential physiological characteristics of strains $\mathrm{DS} 20^{\top}, \mathrm{NBRC} 16140^{\top}$ and other Sphingobium species

Strains: $1, \mathrm{DS}_{2} 0^{\mathrm{T}}$ (Sphingobium lactosutens sp. nov.; data from this study); 2, NBRC $16140^{\mathrm{T}}$ (Sphingobium abikonense sp. nov.; this study); 3, S. olei IMMIB HF- ${ }^{\mathrm{T}}$ (Young et al., 2007); 4, S. rhizovicinum CC-FH12-1 ${ }^{\mathrm{T}}$ (Young et al., 2008); 5, S. xenophagum DSM 6383 ${ }^{\mathrm{T}}$ (Stolz et al., 2000); 6, S. francense $\mathrm{Sp}+{ }^{\mathrm{T}}$ (Pal et al., 2005); 7, S. japonicum UT26 ${ }^{\mathrm{T}}$ (Pal et al., 2005); 8, S. indicum $\mathrm{B} \mathrm{A}^{\mathrm{T}}$ (Pal et al., 2005); 9, S. chungbukensis DJ77 ${ }^{\mathrm{T}}$ (Kim et al., 2000); 10, S. chlorophenolicum ATCC $37097^{\mathrm{T}}$ (Ushiba et al., 2003); 11, S. herbicidovorans $\mathrm{MH}^{\mathrm{T}}$ (Ushiba et al., 2003); 12, S. amiense YT ${ }^{\mathrm{T}}$ (Ushiba et al., 2003); 13, S. yanoikuyae ATCC $51230^{\mathrm{T}}$ (Ushiba et al., 2003); 14, S. cloacae S-3 ${ }^{\mathrm{T}}$ (Ushiba et al., 2003); 15, S. fuliginis TKP ${ }^{\mathrm{T}}$ (Prakash \& Lal, 2006). +, Positive; -, negative; w, weakly positive; ND, no data available.

\begin{tabular}{|c|c|c|c|c|c|c|c|c|c|c|c|c|c|c|c|}
\hline Characteristic & 1 & 2 & 3 & 4 & 5 & 6 & 7 & 8 & 9 & 10 & 11 & 12 & 13 & 14 & 15 \\
\hline \multicolumn{16}{|l|}{ Acid from: } \\
\hline L-Arabinose & + & + & + & + & + & + & + & + & + & - & + & - & + & - & + \\
\hline D-Galactose & + & + & $\mathrm{ND}$ & + & - & + & + & + & + & $\mathrm{ND}$ & $\mathrm{ND}$ & $\mathrm{ND}$ & + & $\mathrm{ND}$ & ND \\
\hline D-Glucose & + & + & + & + & + & + & + & + & + & + & + & + & + & - & + \\
\hline Maltose & + & + & + & + & + & ND & $\mathrm{ND}$ & ND & + & - & + & + & + & - & + \\
\hline D-Mannose & - & + & - & + & - & - & - & - & + & - & - & - & - & - & ND \\
\hline D-Xylose & + & + & + & $\mathrm{ND}$ & $+^{*}$ & + & + & + & + & $\mathrm{ND}$ & $\mathrm{ND}$ & $\mathrm{ND}$ & $\mathrm{ND}$ & $\mathrm{ND}$ & + \\
\hline Catalase & - & - & + & - & + & + & + & + & + & ND & $\mathrm{ND}$ & + & ND & ND & + \\
\hline Urease & - & + & $\mathrm{ND}$ & $\mathrm{ND}$ & $-{ }^{*}$ & $\mathrm{ND}$ & $\mathrm{ND}$ & $\mathrm{ND}$ & - & + & - & - & - & - & - \\
\hline Citrate utilization & + & + & ND & ND & $-*$ & - & - & - & - & - & - & - & + & - & ND \\
\hline Aesculin hydrolysis & + & + & + & + & + & + & + & - & + & + & + & - & + & - & - \\
\hline Nitrate reduction & $\mathrm{W}$ & - & - & + & $-*$ & ND & ND & ND & - & - & - & - & - & - & $\mathrm{W}$ \\
\hline
\end{tabular}

${ }^{\star}$ Data were from this study.

amikacin (30), polymyxin B (30), neomycin (30) and oxytetracycline (30) and resistant to ampicillin (10) and penicillin (10). Major fatty acids are $18: 1 \omega 7 c, 14: 02-\mathrm{OH}$, $16: 0$ and summed feature $3(16: 1 \omega 7 c$ and/or $16: 1 \omega 6 c)$. The polar lipid profile contains phosphatidylmonomethylethanolamine, phosphatidylethanolamine, phosphatidylglycerol, phosphatidyldimethylethanolamine, diphosphatidylglycerol, sphingoglycolipid, phosphatidylcholine and an unidentified polar lipid.

The type strain, DS20 $20^{\mathrm{T}}\left(=\mathrm{CCM} 7540^{\mathrm{T}}=\right.$ MTCC $\left.9471^{\mathrm{T}}\right)$, was isolated from a $\mathrm{HCH}$ dump site in Ummari village at Lucknow, India.

\section{Description of Sphingobium abikonense sp. nov.}

Sphingobium abikonense (a.bi.ko.nen'se. N.L. neut. adj. abikonense pertaining to Abiko, where the type strain was isolated).

Cells are Gram-negative, aerobic, non-spore-forming, rodshaped $(1.5 \mu \mathrm{m} \times 0.4 \mu \mathrm{m})$ and motile by means of a single polar flagellum $(>5.2 \mu \mathrm{m})$. Produces yellow-coloured, small, smooth and circular colonies. Grows at $20-37{ }^{\circ} \mathrm{C}$ (optimum, $28{ }^{\circ} \mathrm{C}$ ) and $\mathrm{pH}$ 6-10 (optimum, $\mathrm{pH}$ 7). Does not grow in $>5 \% \mathrm{NaCl}$. Produces acid from D-glucose, Dgalactose, L-arabinose, D-xylose, cellobiose, trehalose, maltose, rhamnose and D-mannose but not from lactose, D-fructose, sucrose, D-ribose, D-mannitol, raffinose, melibiose, meso-inositol, adonitol or sorbitol. Positive for aesculin hydrolysis, citrate utilization and urease activity but negative for nitrate reduction, gelatinase, xanthine and hypoxanthine hydrolysis, DNase and catalase. Sensitive to ( $\mu \mathrm{g}$ per disc): ciprofloxacin (5), rifampicin (5), kanamycin (30), vancomycin (30), gentamicin (10), tetracycline (30), chloramphenicol (30), amikacin (30), polymyxin B (30), neomycin (30), oxytetracycline (30) and resistant to ampicillin (10) and penicillin (10). Major fatty acids are $18: 1 \omega 7 c, 14: 02-\mathrm{OH}, 16: 0$ and summed feature 3

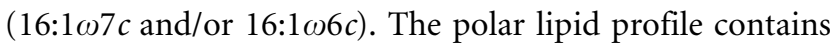
phosphatidylmonomethylethanolamine, phosphatidylethanolamine, phosphatidylglycerol, phosphatidyldimethylethanolamine, diphosphatidylglycerol, sphingoglycolipid and an unidentified polar lipid.

The type strain, NBRC $16140^{\mathrm{T}}\left(=\mathrm{IAM} 12404^{\mathrm{T}}=\mathrm{KCTC}\right.$ $\left.2864^{\mathrm{T}}\right)$, was isolated from oil-contaminated soil.

\section{Acknowledgements}

This work was supported by grants from Department of Biotechnology (DBT) and National Bureau of Agriculturally Important Micro-organisms (NBAIM), Government of India. H. K. acknowledges CSIR, Government of India for providing the research fellowship. We would also like to thank J. P. Euzéby for etymological advice.

\section{References}

Anzai, Y., Kim, H., Park, J. Y., Wakabayashi, H. \& Oyaizu, H. (2000). Phylogenetic affiliation of the pseudomonads based on 16S rRNA sequence. Int J Syst Evol Microbiol 50, 1563-1589.

Arden-Jones, M. P., McCarthy, A. J. \& Cross, T. (1979). Taxonomic and serological studies on Micropolyspora faeni and Micropolyspora 
strains from soil bearing the specific epithet rectivirgula. J Gen Microbiol 115, 343-354.

Busse, H. J., Kämpfer, P. \& Denner, E. B. M. (1999). Chemotaxonomic characterization of Sphingomonas. J Ind Microbiol Biotechnol 23, 242-251.

Christensen, W. B. (1946). Urea decomposition as a means of differentiating Proteus and paracolon cultures from each other and from Salmonella and Shigella types. J Bacteriol 52, 461-466.

Collins, C. H., Lyne, P. M. \& Grange, J. M. (1989). Microbiological Methods, 6th edn. London: Butterworth.

Cowan, S. T. \& Steel, K. J. (1965). Manual for the Identification of Medical Bacteria. London: Cambridge University Press.

Farmer, J. J., III (1999). Enterobacteriaceae: introduction and identification. In Manual of Clinical Microbiology, 7th edn, pp. 442458. Edited by P. R. Murray, E. J. Baron, M. A. Pfaller, F. C. Tenover \& R. H. Yolken. Washington, DC: American Society for Microbiology.

Felsenstein, J. (1993). PHYLIP (phylogeny inference package), version 3.5c. Distributed by the author. Department of Genome Sciences, University of Washington, Seattle, USA.

Fitch, W. M. (1971). Toward defining the course of evolution: minimum change for a specific tree topology. Syst Zool 20, 406-416.

Gordon, R. E., Barnett, D. A., Handerhan, J. E. \& Pang, C. H.-N. (1974). Nocardia coeliaca, Nocardia autotrophica, and the nocardin strain. Int J Syst Bacteriol 24, 54-63.

Grimes, D. J., Woese, C. R., MacDonell, M. T. \& Colwell, R. R. (1997). Systematic study of the genus Vogesella gen. nov. and its type species, Vogesella indigofera comb. nov. Int J Syst Bacteriol 47, 19-27.

Gupta, S. K., Kumari, R., Prakash, O. \& Lal, R. (2008). Pseudomonas panipatensis sp. nov., isolated from an oil-contaminated site. Int J Syst Evol Microbiol 58, 1339-1345.

Gupta, S. K., Lal, D. \& Lal, R. (2009). Novosphingobium panipatense sp. nov. and Novosphingobium mathurense sp. nov., from oil-contaminated soil. Int J Syst Evol Microbiol 59, 156-161.

Jukes, T. H. \& Cantor, C. R. (1969). Evolution of protein molecules. In Mammalian Protein Metabolism, vol. 3, pp. 21-132. Edited by H. N. Munro. New York: Academic Press.

Kim, S. J., Chun, J., Bae, K. S. \& Kim, Y. C. (2000). Polyphasic assignment of an aromatic-degrading Pseudomonas sp., strain DJ77, in the genus Sphingomonas as Sphingomonas chungbukensis sp. nov. Int J Syst Evol Microbiol 50, 1641-1647.

Kuykendall, L. D., Roy, M. A., O’Neill, J. J. \& Devine, T. E. (1988). Fatty acids, antibiotic resistance, and deoxyribonucleic acid homology groups of Bradyrhizobium japonicum. Int J Syst Bacteriol 38, 358-361.

Lee, K. B., Liu, C. T., Anzai, Y., Kim, H., Aono, T. \& Oyaizu, H. (2005). Hierarchical system of the 'Alphaproteobacteria': description of Hyphomonadaceae fam. nov., Xanthobacteraceae fam. nov. and Erythrobacteraceae fam. nov. Int J Syst Evol Microbiol 55, 1907-1919.

McCarthy, A. J. \& Cross, T. (1984). A taxonomic study of Thermomonospora and other monosporic actinomycetes. J Gen Microbiol 130, 5-25.

Miller, L. T. (1982). Single derivatization method for the routine analysis of whole-cell fatty acid methyl esters, including hydroxyl acids. J Clin Microbiol 16, 584-586.

Nohynek, L. J., Nurmiaho-Lassila, E. L., Suhonen, E. L., Busse, H. J., Mohammadi, M., Hantula, J., Rainey, F. \& Salkinoja-Salonen, M. S. (1996). Description of chlorophenol-degrading Pseudomonas sp. strains $\mathrm{KF}^{\mathrm{T}}$, KF3, and NKF1 as a new species of the genus Sphingomonas, Sphingomonas subarctica sp. nov. Int J Syst Bacteriol 46, 1042-1055.
Pal, R., Bala, S., Dadhwal, M., Kumar, M., Dhingra, G., Prakash, O., Prabagaran, S. R., Shivaji, S., Cullum, J. \& other authors (2005). Hexachlorocyclohexane-degrading bacterial strains Sphingomonas paucimobilis B90A, UT26 \& Sp +, having similar lin genes, represent three distinct species, Sphingobium indicum sp. nov., Sphingobium japonicum sp. nov. and Sphingobium francense sp. nov. and reclassification of [Sphingomonas] chungbukensis as Sphingobium chungbukensis comb. nov. Int J Syst Evol Microbiol 55, 1965-1972.

Prakash, O. \& Lal, R. (2006). Description of Sphingobium fuliginis sp. nov., a phenanthrene-degrading bacterium from a fly ash dumping site, and reclassification of Sphingomonas cloacae as Sphingobium cloacae comb. nov. Int J Syst Evol Microbiol 56, 2147-2152.

Saitou, N. \& Nei, M. (1987). The neighbor-joining method: a new method for reconstructing phylogenetic trees. Mol Biol Evol 4, 406425.

Singh, A. \& Lal, R. (2009). Sphingobium ummariense sp. nov., a novel hexachlorocyclohexane $(\mathrm{HCH})$-degrading bacterium, isolated from HCH-contaminated soil. Int J Syst Evol Microbiol 59, 162-166.

Smibert, R. M. \& Krieg, N. R. (1994). Phenotypic characterization. In Methods for General and Molecular Bacteriology, pp. 607-654. Edited by P. Gerhardt, R. G. E. Murray, W. A. Wood \& N. R. Krieg. Washington, DC: American Society for Microbiology.

Spröer, C., Lang, E., Hobeck, P., Burghardt, J., Stackebrandt, E. \& Tindall, B. J. (1998). Transfer of Pseudomonas nautica to Marinobacter hydrocarbonoclasticus. Int J Syst Bacteriol 48, 1445-1448.

Stolz, A., Schmidt-Maag, C., Denner, E. B. M., Busse, H.-J., Egli, T. \& Kämpfer, P. (2000). Description of Sphingomonas xenophaga sp. nov. for strains $\mathrm{BN6}^{\mathrm{T}}$ and $\mathrm{N}, \mathrm{N}$ which degrade xenobiotic aromatic compounds. Int J Syst Evol Microbiol 50, 35-41.

Takeuchi, M., Hamana, K. \& Hiraishi, A. (2001). Proposal of the genus Sphingomonas sensu stricto and three new genera, Sphingobium, Novosphingobium and Sphingopyxis, on the basis of phylogenetic and chemotaxonomic analysis. Int $J$ Syst Evol Microbiol 51, 1405-1417.

Thompson, J. D., Gibson, T. J., Plewniak, F., Jeanmougin, F. \& Higgins, D. G. (1997). The CLUSTAL_X windows interface: flexible strategies for multiple sequence alignment aided by quality analysis tools. Nucleic Acids Res 25, 4876-4882.

Ushiba, Y., Takahara, Y. \& Ohta, H. (2003). Sphingobium amiense sp. nov., a novel nonylphenol-degrading bacterium isolated from a river sediment. Int J Syst Evol Microbiol 53, 2045-2048.

Vandamme, P., Holmes, B., Vancanneyt, M., Coenye, T., Hoste, B., Coopman, R., Revets, H., Lauwers, S., Gillis, M. \& other authors (1997). Occurrence of multiple genomovars of Burkholderia cepacia in cystic fibrosis patients and proposal of Burkholderia multivorans sp. nov. Int J Syst Bacteriol 47, 1188-1200.

Van de Peer, Y. \& De Wachter, R. (1994). TREECON for Windows: a software package for the construction and drawing of evolutionary trees for the Microsoft Windows environment. Comput Appl Biosci 10, 569-570.

Viallard, V., Poirier, I., Cournoyer, B., Haurat, J., Wiebkin, S., OphelKeller, K. \& Balandreau, J. (1998). Burkholderia graminis sp. nov., a rhizospheric Burkholderia species, and reassessment of [Pseudomonas] phenazinium, [Pseudomonas] pyrrocinia and [Pseudomonas] glathei as Burkholderia. Int J Syst Bacteriol 48, 549-563.

Wayne, L. G., Brenner, D. J., Colwell, R. R., Grimont, P. A. D., Kandler, O., Krichevsky, M. I., Moore, L. H., Moore, W. E. C., Murray, R. G. E. \& other authors (1987). International Committee on Systematic Bacteriology. Report of the ad hoc committee on reconciliation of approaches to bacterial systematics. Int $J$ Syst Bacteriol 37, 463-464. 
Yamada, K., Minoda, Y., Kodama, K., Nakatani, S. \& Akasaki, T. (1968). Microbial conversion of petro-sulfur compounds. Part I. Isolation and identification of dibenzothiophene-utilizing bacteria. Agric Biol Chem 32, 840-845.

Young, C.-C., Ho, M.-J., Arun, A. B., Chen, W.-M., Lai, W.-A., Shen, F.-T., Rekha, P. D. \& Yassin, A. F. (2007). Sphingobium olei sp. nov., isolated from oil-contaminated soil. Int J Syst Evol Microbiol 57, 26132617.

Young, C.-C., Arun, A. B., Kämpfer, P., Busse, H.-J., Lai, W.-A., Chen, W.-M., Shen, F.-T. \& Rekha, P. D. (2008). Sphingobium rhizovicinum sp. nov., isolated from rhizosphere soil of Fortunella hindsii (Champ. ex Benth.) Swingle. Int J Syst Evol Microbiol 58, 1801-1806. 